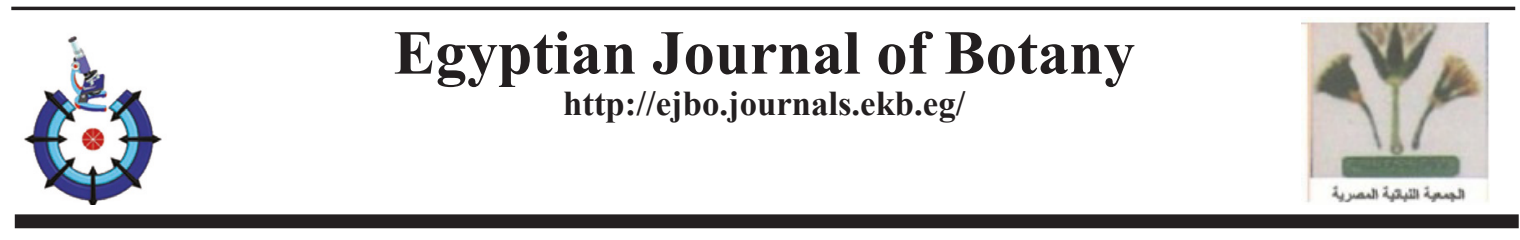

\title{
Eco-Friendly Green Synthesis of Silver Nanoparticles from Egyptian Honey: Evaluating its Antibacterial Activities
}

Ghada A. Youssef

Botany and Microbiology Department, Faculty of Science, Alexandria University, Alexandria, 21431, Egypt.

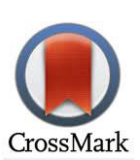

$\mathbf{T}$

HIS RESEARCH article describes a strong approach for the green synthesis of silver nanoparticles (AgNPs) that employs a local black seed honey (BSH). Honey was chosen as the eco-friendly reducing and stabilizing agent replacing most reported reducing agents which represent highly biological risk to the society and environment. Honey reduced silver ions into AgNPs after 20min in a stirred reaction mixture. Nanoparticles of different sizes were obtained, and the solution turned black over time. The antibacterial activity of AgNPs was investigated against eight pathogenic bacterial strains; five Gram-negative and three Gram-positive. AgNPs were potentially effective against the Gram-negative more than Gram-positive bacterial strains. E. coli and P. aeruginosa were the highly susceptible strains with $6.3 \mu \mathrm{g} / \mathrm{ml}$ minimum inhibitory concentrations (MICs). The AgNPs were characterized by perform UV-visible spectroscopy, fourier transform infrared spectroscopy (FTIR), transmission electron microscopy (TEM) and scanning electron microscopy (SEM) imaging. The colloid obtained at a $\mathrm{pH}$ of 9 was found to be spherical in shape and was distributed with a certain amount of agglomeration. An intense surface plasmon resonance band at $400 \mathrm{~nm}$ in the UV-visible spectrum clearly revealed the formation of AgNPs after 72hr. TEM showed spherically shaped AgNPs, and the sizes of the nanoparticles ranged from 25-70nm. AgNPs had broad spectrum antibacterial property thus they can be explored further for medical and therapeutic applications.

Keywords: Black seed honey (BSH), Green synthesis, Characterization of silver nanoparticles, Pathogenic strains, Antibacterial activity.

\section{Introduction}

One of the most promising and recent areas of research in modern science is nanotechnology (Albrecht et al., 2006). Nanocrystalline metal particles (in particular AgNPs) have found tremendous applications in the field of high sensitivity biomolecular detection and diagnostics (Schultz et al., 2000), antimicrobials and therapeutics (Elechiguerra et al., 2005; Ouf et al., 2015, 2017), catalysis (Crooks et al., 2001) and micro-electronics (Gittins et al., 2000). The use of chemical and physical methods in the synthesis of nanoparticles is very expensive and cumbersome and leads to the presence of some toxic compounds and may have adverse effects in their applications (Parashar et al., 2009). Therefore, the development of green synthesis of nanoparticles is an important aspect of nanoscience and nanotechnology by growing environmentally benign nanoparticles (Venu et al., 2011). Synthesis of nanoparticles by green approach is an emerging field because of its various advantages over the other processes like nontoxic, ecofriendly and low cost. Researchers have used biological extracts for the synthesis of nanoparticles by adopting simple protocols, involving the process of reduction of metal ions by using biological extracts as a source of reductants either extracellularly or intracellularly (Fayaz et al., 2009; Kamel et al., 2016; Sharma et al., 2009).

"Corresponding author e-mail: aminghada66@gmail.com

Tel.:(020100) 407-3123, Fax: 202033911794

Received 10/12/2018; Accepted 12/5/2019

DOI: $10.21608 /$ ejbo.2019.6597.1261

Edited by: Prof. Dr. Salama A. Ouf, Faculty of Science, Cairo University, Giza 12613, Egypt.

(C)2019 National Information and Documentation Center (NIDOC) 
Many bacterial and fungal species have been used for AgNP synthesis (Bhainsa \& D'souza, 2006; Song \& Kim, 2009). However, most of them have been reported to accumulate AgNP intracellularly. Microbe mediated synthesis is not of industrial feasibility due to the requirements of highly aseptic conditions and their maintenance. Therefore; the use of plant extracts for this purpose is potentially advantageous over microorganisms due to the ease of improvement, the less biohazard and elaborate process of maintaining cell cultures (Kalishwaralal et al., 2010). Honey has recently been identified as another exceptional candidate that has yet to be fully explored by researchers around the world. The use of honey to synthesize AgNPs in water was recently reported (Philip, 2010) for the development of cost-effective and environmentally benign synthesis (Philip, 2009; 2010). Eco-friendly honey contains ingredients such as glucose and fructose that are used as capping and reducing agents in the synthesis of nanoparticles. In addition, it has extraordinary healing properties that are attributed mainly to its acidic $\mathrm{pH}$ and the presence of hydrogen peroxide (French et al., 2005). It replaced synthetic reducing agents such as hydrazine and dimethyl formamide, which are not completely environmentally safe. Natural honey is a sweet viscous fluid produced by bees. Honey consists of $80-85 \%$ carbohydrates, $15-17 \%$ water, $0.3 \%$ proteins, $0.2 \%$ ashes and minor quantities of amino acids and vitamins as well as low concentrations of other components (Moniruzzaman et al., 2014). Honey mediated biological synthesis has advantages over other types of biological methods (Venu et al., 2011), including the avoidance of elaborate processes such as drying plant materials and maintaining cell cultures. In recent years, studies have focused on the composition of honeys and their biological properties such as their antioxidant, anti-inflammatory and antimicrobial activities. The components of honey that are reportedly responsible for its antioxidant effects are flavonoids, phenolic acids, ascorbic acid, catalase, peroxidase, carotenoids and the products of Maillard reactionswere investigated by Chua et al. (2013). In addition, honey helps providing a protective barrier to prevent infections within wound environments as well as in the treatment of skin ulcers and gastrointestinal disorders (Lusby et al., 2005; Dahl et al., 2007).

The green synthesis of AgNPs involves three primary steps, that must be evaluated in accordance with green chemistry perspectives (Dahl et al., 2007) selection of the solvent medium (Hutchison \& Rodriguez, 2008) selection of an environmentally benign reducing agent, and (Anastas \& Warner, 2000; Raveendran et al., 2003) selection of non-toxic substances for AgNP stability. Based on this approach, we have reviewed green chemistry type AgNP synthesis processes.

Advancements in nanotechnology have prompted microbiologists to apply metal nanoparticles as an effective method to control certain pathogenic microbes that are involved in infectious diseases (Nanda \& Saravanan, 2009; Allahverdiyev et al., 2011; Li et al., 2011; Rosarin \& Mirunalini, 2011; Singh et al., 2011; Ahmed et al., 2015; Prabu \& Johnson, 2015). It is expected that the high specific surface area and high fraction of surface atoms on AgNPs will lead to high antimicrobial activity when compared with that of bulk silver metal (Cho et al., 2005). These nanoparticles are now primarily used as catalysts or antibacterial/antifungal agents (Anuj \& Ishnava, 2013). One approach for countering bacterial drug resistance is the application of metal composites, especially at the nanoscale, to control bacterial infections. Scientists are developing new ways to control resistant pathogens (Nambiar et al., 2014).

In vitro evidence shows that AgNPs exert a unique antibacterial action on cells. There is an electrostatic attraction between $\mathrm{nAg}^{+}$and the negative charge on bacterial cell membranes and $\mathrm{nAg}^{+}$binds to the modified phospholipid bilayer and induces massive proton leakage (Dibrov et al., 2002). When $\mathrm{nAg}^{+}$anchors to the bacterial cell wall and causes structural change by forming irregular-shaped "pits" on the bacterial outer membrane, the permeability of the membrane changes and it becomes porous (Sondi \& SalopekSondi, 2004; Mirzajani et al., 2011). The cell will then progressively release lipopolysaccharides and membrane protein, which will ultimately cause the cell to die (Li et al., 2010). Pal et al. demonstrated that the surface area to volume ratio of AgNPs and the crystallographic surface structures are important factors that determine the antibacterial activity of AgNPs (Pal et al., 2007).

The production of AgNPs is relatively inexpensive, and the addition of these particles into goods such as plastics, clothing, creams and soaps increases their market value. New classes of 
compounds that include nanoparticle-antibiotic conjugates are undergoing clinical evaluations (Ping et al., 2005; Rai et al., 2009; Fayaz et al., 2010; Sekhon, 2010; Allahverdiyev et al., 2011; Kollef et al., 2011). The collaboration between nanotechnology and nanomedicine resulted in the emergence of new trend in both therapeutic and pharmaceutical fields in order to reveal novel therapeutic and diagnostic tools for human use (Asharani et al., 2009; Blanco et al., 2015).

\section{Materials and Methods}

\section{Bacterial strains}

Eight pathogenic bacterial strains comprising both Gram-positive and Gram-negative species were used. These bacteria were kindly provided by members of the culture collection of Genetic Engineering and Biotechnology Research Institute in Scientific Research and Technology Applications City, Egypt. Five strains of Gramnegative (Escherichia coli, Proteus mirabilis, Klebsiella pneumonia, Pseudomonas aeruginosa and Shigella spp.) and three strains of Grampositive (Staphylococcus aureus, Streptococcus mutans and Bacills subtilis) bacteria. All species were subcultured on nutrient agar and incubated aerobically at $37^{\circ} \mathrm{C}$. The organisms were maintained in the laboratory on nutrient agar slopes at $4^{\circ} \mathrm{C}$.

\section{Honey samples}

The natural local honey (black seed; BSH) used in this study was purchased from AlDakhakhny market of Alexandria, Egypt.

Honey-mediated biosynthesis of AgNPs

Silver nitrate was purchased from SigmaAldrich (St. Louis, MO). An aqueous solution $(0.1 \mathrm{M})$ of silver nitrate $\left(\mathrm{AgNO}_{3}\right)$ was prepared and used to synthesize AgNPs. Five millilitres of honey was added to $95 \mathrm{ml}$ of $0.1 \mathrm{M}$ aqueous $\mathrm{AgNO}_{3}$ and stirred well for $1 \mathrm{~min}$ to induce reduction into $\mathrm{Ag}+$ ions. The intensity of the colour was then investigated.

Characterization of the biologically synthesized AgNPs

$U V$ - visible spectrum analysis

UV-visible spectra were measured with a UVvisible spectrophotometer (T70 Split-Beam UV/ VIS Spectrophotometer, England). The reduction of pure $\mathrm{Ag}^{+}$ions was monitored by measuring the UV-visible spectrum of the reaction medium over a range from 300 to $900 \mathrm{~nm}$. One millilitre of the sample was pipetted into a test tube after incubation for 20min and subsequently analysed at room temperature (Philip \& Unni, 2011). The two parameters that were optimized were the $\mathrm{pH}$ and the reaction incubation time, which were identified as the factors that affected AgNP yields.

$p H$

The above mentioned procedure was performed to optimize the $\mathrm{pH}$, the reaction $\mathrm{pH}$ values were maintained at 5, 6, 7, 8 and 9. The $\mathrm{pH}$ values were adjusted using $0.1 \mathrm{~N} \mathrm{HCl}$ and $0.1 \mathrm{~N}$ $\mathrm{NaOH}$. The absorbance of the resulting solutions was measured spectrophotometrically after $24 \mathrm{hr}$.

\section{Incubation time}

The optimization of reaction mixture incubation times was required to complete the reaction. The above mentioned procedure was repeated after different incubation periods of $20 \mathrm{~min}, 24,48$ and $72 \mathrm{hr}$ at a $9 \mathrm{pH}$ value. The absorbance of the resulting solutions was measured spectrophotometrically.

\section{FTIR spectroscopy}

FTIR spectroscopy is useful for probing the chemical composition of the AgNP surface and the capping agents on the nanoparticles. A drop of sample is directly placed on the $\mathrm{ZnSe}$ crystal with a medicine dropper. A 9d spectrometer then records the IR spectrum of the sample. AgNPs were evaluated for their fluorescence characteristics with a Perkin-Elmer LS 50B luminescence spectrophotometer (Spectrum one, Perkin Elmer, Germany). Spectra over the wavelength range of 4000-650 cm- ${ }^{-1}$ were recorded (Honary et al., 2013).

\section{TEM}

The size and size distribution of AgNPs in an aqueous solution were measured using TEM. A drop of synthesized AgNPs was placed on a carbon coated copper grid and loaded onto a specimen holder. TEM micrographs of the sample were taken using the JEOL JSM 100cx. The transmission electron microscope was operated at an accelerating voltage of $80.0 \mathrm{kV}$. TEM provided further insight into the morphology and particle size distribution profile of the AgNPs and revealed a pattern similar to that described of pervious reports of synthesized AgNPs.

SEM

A scanning electron microscope (JOEL, 
Japan, Model-6360) was employed to image the sample surface via scanning with a high energy electron beam. This scanning was undertaken to identify the sizes and shapes of AgNPs that were biosynthesized using honey. The colloidal solution containing AgNPs was centrifuged at $6000 \mathrm{rpm}$ for $10 \mathrm{~min}$ and the pellet was mixed and suspended in a small amount of sterilized double distilled water. A small amount of the suspension was sprayed on a glass slide, creating a thin film that was placed carefully on a glass cover slip followed by air-drying. The sample was then coated with gold using a coater. The sizes of the AgNPs are indicated in the images.

\section{Assessing the antibacterial activity of synthesized AgNPs \\ Agar well diffusion method}

The biosynthesized AgNPs were tested for their antibacterial activity against eight pathogenic strains of Gram-negative and Grampositive bacteria by the well diffusion method (Ibrahim, 2015). Mueller-Hinton agar plates were swabbed with $100 \mu$ of each tested strain using a sterile cotton swab. Wells approximately $5 \mathrm{~mm}$ in diameter were produced with the help of a sterile gel puncture. Using a micropipette, synthesized AgNPs at $5 \mathrm{mg} / \mathrm{ml}$ were loaded at concentrations of $25,50,75,100$ and $125 \mu \mathrm{l} /$ well. A control sample (BSH) was used to detect the antimicrobial activity of the natural honey. The plates were incubated at $37^{\circ} \mathrm{C}$ for $24 \mathrm{hr}$. The antibacterial activity was expressed as the diameter of the inhibition zone, as measured in millimetres. The assays were implemented in triplicate. The mean values for the inhibition zones were detected. The inhibition zones were measured and individually compared with those of the $\mathrm{BSH}, \mathrm{AgNO}_{3}$ solution and AgNPs.

Determination of minimum inhibitory concentrations (MICs)

The MIC of the synthesized nanoparticles was tested using a standard microdilution method (Sarker et al., 2007). MIC is defined as the lowest concentration of an antimicrobial agent that inhibits the growth of a microorganism after overnight incubation (Qi et al., 2004). MICs were determined by monitoring the growth of the bacteria in a microplate reader at $600 \mathrm{~nm}$. Serial two-fold dilutions of AgNP solutions were prepared in sterile 96-well plates. One hundred microlitres $(100 \mu \mathrm{l})$ of the nutrient broth was added to each well with the exception of row one, which was the positive control. Then, $100 \mu$ l of the nanoparticles were added to each well of the first row (row 1), starting with the positive control, followed by the negative control. Fifty microlitres of freshly prepared bacterial suspension were mixed with the prepared extract dilutions, and they were incubated at $37^{\circ} \mathrm{C}$ for $24 \mathrm{hr}$. All experiments were performed in triplicate. Bacterial growth was measured as the increase in absorbance at $600 \mathrm{~nm}$ using a spectrophotometer (Williams et al., 2006).

\section{Statistical analysis}

All assays were performed in triplicate, and the experiments were repeated at least three times. The results are presented as the means $\pm \mathrm{SD}$. All experimental data were compared using Student's t-test. A p value of less than 0.05 was considered statistically significant (D Steel \& Torrie, 1986).

\section{$\underline{\text { Results and Discussion }}$}

\section{Honey mediated biosynthesis of AgNPs}

An aqueous solution (0.1M) of $\mathrm{AgNO}_{3}$ was prepared and used to synthesize AgNPs. Five millilitres of honey were added to $95 \mathrm{ml}$ of $0.1 \mathrm{M}$ aqueous $\mathrm{AgNO}_{3}$ and stirred well for $1 \mathrm{~min}$ to initiate the reduction into $\mathrm{Ag}+$ ions. The intensity of the colour increased with increasing time as showed in Fig. 1. The colour of the resulting samples changed rapidly from amber to dark brown after $20 \mathrm{~min}$ indicating the formation of AgNPs due to the reduction of silver metal ions from Ag+ into AgNPs (Philip, 2010).

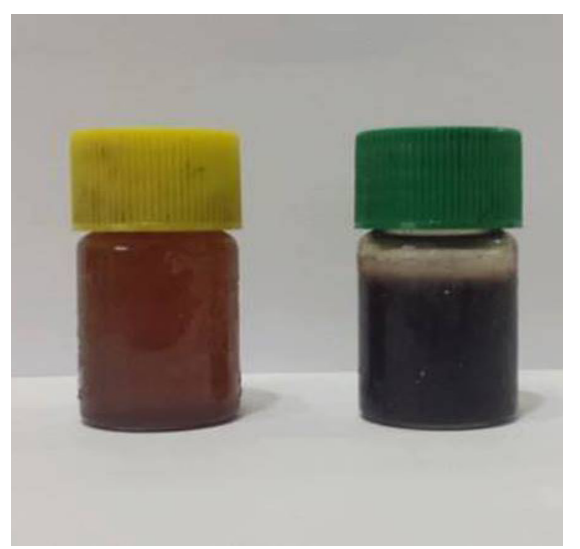

Fig. 1. Colour intensity, Left: Natural BSH; right: Synthesized AgNPs after 20 min.

Characterization of biologically synthesized
AgNPs
UV-visible spectroscopic analysis
Metallic nanoparticles display characteristic


optical absorption spectra known as surface plasmon resonance (SPR) in the UV-visible region. This effect becomes influential when the wavelength of the valence electrons is equal to or less than the size of the particle,(Ahmad \& Sharma, 2012).

The two parameters that were optimized were the $\mathrm{pH}$ and the reaction incubation time, which were identified as the factors that affected AgNP yields. The first factor under consideration was the $\mathrm{pH}$ of the reaction mixture. Large nanoparticles formed at a lower $\mathrm{pH}(\mathrm{pH} 5)$ that suppresses the formation of AgNPs (Fig. 2 a); this phenomenon may be attributable to the instability of the nanoparticles at an acidic $\mathrm{pH}$ (Sadowski et al., 2008). The UV-visible spectra showed a distinct maximum absorbance at 400nm at $\mathrm{pH} 9$, whereas small and highly dispersed nanoparticles were detected. A similar result was observed in previous study, which showed that highly monodispersed nanoparticles were obtained at a $\mathrm{pH}$ of 10 (Ndikau et al., 2017). We next investigated the reaction incubation time, and the UV-visible spectrum of AgNPs was recorded (Fig. 2 b). The rate of silver ion reduction was slow during the first $20 \mathrm{~min}$, and then the intensity of the SPR peak showed a gradual increase until reaching its maximum absorption with a sharper peak at 400nm after $72 \mathrm{hr}$. The time required for a complete reduction in metal ions during the biosynthesis of metal nanoparticles using bacteria and fungi ranges from 24 to $124 \mathrm{hr}$ (Korbekandi et al., 2009). The sharpness of the absorbance peak depends on the size of the synthesized nanoparticle (Philip, 2010). The broadening of the peak at that wavelength is attributed to the formation of poly dispersed AgNPs, (Ponarulselvam et al., 2012).

\section{FTIR analysis}

To identify the compounds responsible for reducing silver ions, the functional groups present in AgNPs were investigated by FTIR analysis. The FTIR analysis results for this study showed different stretches of bonds over a wave length range from $4000-650 \mathrm{~cm}^{-1}$ at different peaks; $3318 \mathrm{~cm}^{-1}$ and $1636 \mathrm{~cm}^{-1}$ were assigned to the stretching vibrations of primary and secondary amines, respectively. The band at $2119 \mathrm{~cm}^{-1}$ was characteristic of carbonyl group $\mathrm{C}=\mathrm{O}$ - stretching, and the band at $1364 \mathrm{~cm}^{-1}$ corresponds to $\mathrm{C}-\mathrm{N}$ stretching (aliphatic amines) vibrations (Fig. 3). The results obtained by FTIR spectroscopy suggest that honey has the ability to reduce and stabilize the AgNPs (Sheela et al., 2010 and Philip, 2009, 2010). Natural biological components are known to interact with metal salts via these functional groups and to mediate their reduction to nanoparticles (Sheela et al., 2010).

(a)

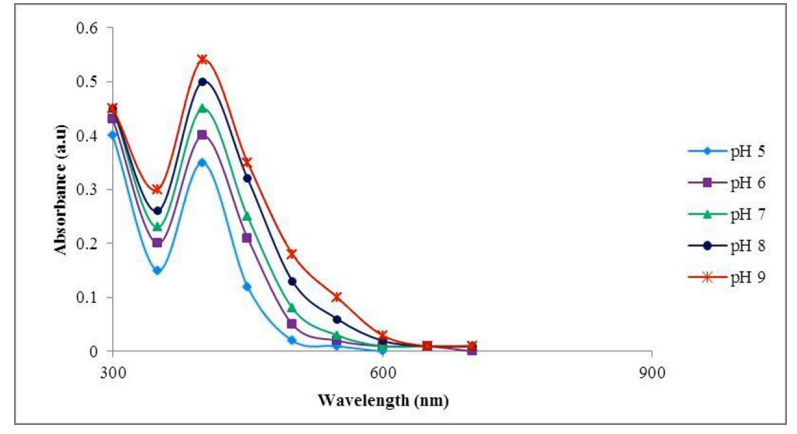

(b)

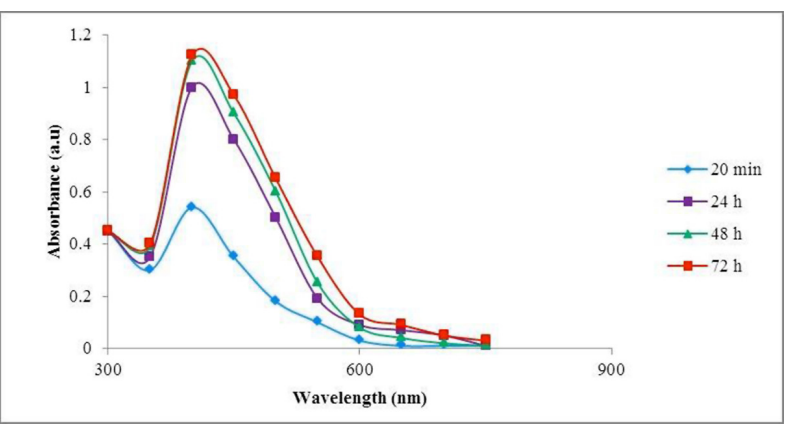

Fig. 2. UV-visible absorption spectra of synthesized AgNPs at different pH values (a) and at different incubation periods for the reaction mixture (b). 


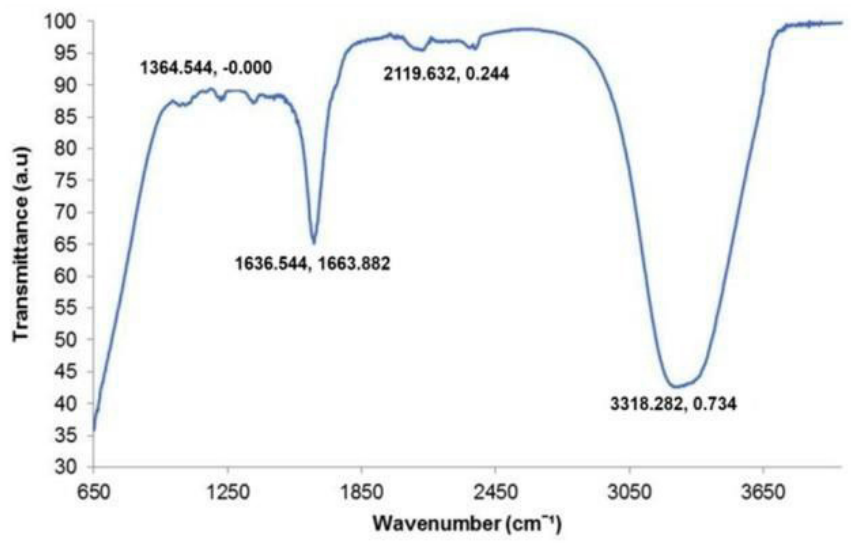

Fig. 3. FTIR spectra of the biosynthesized AgNPs over the wavelength range from $4000-650 \mathrm{~cm}^{-1}$.

Morphological characterization via TEM

TEM is one of the best-adapted techniques for studying the sizes, shapes, and distribution of nanoparticles (Bar et al., 2009). TEM micrographs revealed that the AgNPs were well dispersed and predominantly spherical in shape, while some were irregularly shaped. The AgNPs were widely separated over a range from 5-22nm (Fig. 4 a), and agglomerated AgNPs were also observed in some places, thereby indicating their possible sedimentation at a later time over a range of 1870nm (Fig. 4 b). Similar results have been reported for spherical-shaped AgNPs with an average diameter ranging between 20 and $34 \mathrm{~nm}$ (Jyoti et al., 2016; Kamel et al., 2016; Ndikau et al., 2017). Interestingly, our data suggest that using honey produces smaller AgNPs, which exhibit better antimicrobial and anticancer activities.

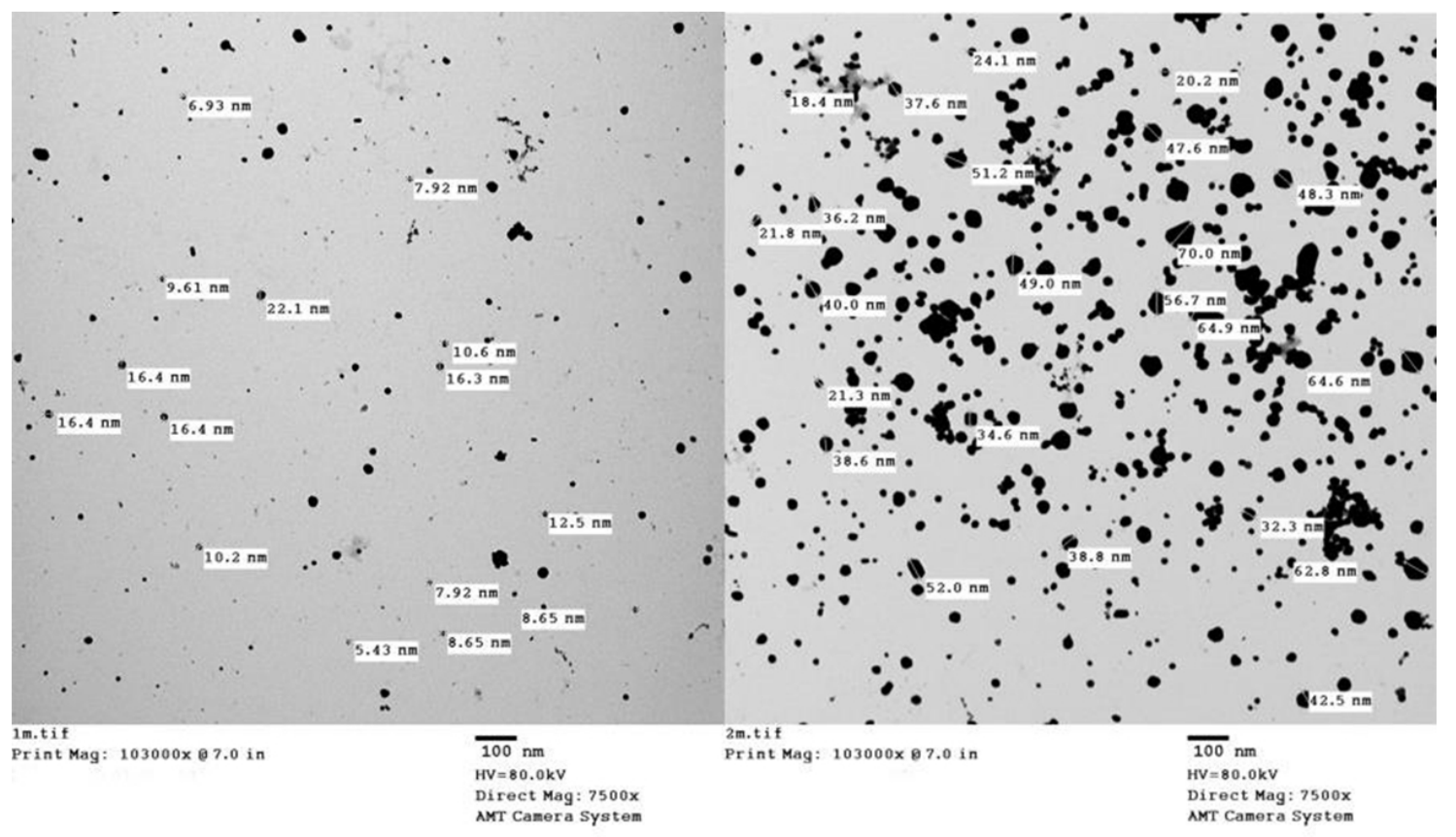

(a)

(b)

Fig.4. TEM micrographs of AgNPs showing spherical shapes over range 5-22nm (a) and agglomerated structures at $18-70 \mathrm{~nm}(\mathrm{~b})$. 
SEM

SEM was employed to analyse the structure of the nanoparticles that formed. According to scanning electron micrographs, the morphology of synthesized AgNPs consisted of spherical nanoparticles with some nanoclusters. The larger silver particles may be attributable to the aggregation of smaller particles, indicating stabilization of the nanoparticles by a capping agent (Priya et al., 2011). The particle sizes obtained here range from $70 \mathrm{~nm}$ to $163 \mathrm{~nm}$ (Fig. 5 a) and between $26 \mathrm{~nm}$ and $91 \mathrm{~nm}$ (Fig. 5 b). These results suggested that AgNPs are synthesized due to the actions of the honey, which acts as a good capping and reducing agent for nanoparticles biosynthesis.

Antibacterial activity of the synthesized AgNPs Agar well diffusion method

The results revealed that AgNPs were potentially effective with variable potency in suppressing microbial growth of the pathogenic bacterial strains (Figs. 6, 7). E. coli and P. aeruginosa were the most susceptible strains to AgNPs with larger inhibition zones of 29.33 and $25.00 \mathrm{~mm}$ at $125 \mu 1$, respectively, followed by $K$. pneumoniae with $23.33 \mathrm{~mm}$ zone of inhibition at $100 \mu 1$ (Fig. 6). The most susceptible Grampositive bacteria was Staphylococcus aureus with inhibition zone $20.00 \mathrm{~mm}$ followed by 19.00 and $18.20 \mathrm{~mm}$ for Streptococcus mutans and Bacillus subtilis, respectively. Natural BSH (as the control) showed moderate antibacterial activity compared with the nanoparticles. The combination of $\mathrm{BSH}$ with $\mathrm{AgNO}_{3}$ to form $\mathrm{AgNPs}$ enhances its antimicrobial activity (Fig. 6). The results revealed larger inhibition zones for Gramnegative than for the other tested Gram-positive bacteria of both natural honey and nanoparticles.
This result could be attributed to differences in bacterial cell walls, Gram-negative have thinner cell walls in comparison to Gram-positive bacteria (Shrivastava et al., 2007; Rai et al., 2009). Several studies have explained the bactericidal effects of $\mathrm{AgNPs}$; they may attach to the negatively charged cell surface, alter the physical and chemical properties of cell membranes and the cell wall and disturb important functions such as permeability, osmoregulation, electron transport and respiration (Sondi \& Salopek-Sondi, 2004; Kvitek et al., 2008; Nel et al., 2009; Su et al., 2009; Marambio-Jones \& Hoek, 2010). AgNPs generate free radicals, which damage the bacterial cell membrane (Sondi \& Salopek-Sondi, 2004; Mirzajani et al., 2011). It is also possible that AgNPs not only interact with the membrane surface but also penetrate bacteria (Morones et al., 2005).

Determination of minimum inhibitory concentrations (MICs) of the most susceptible strains

The MICs of the AgNPs against the most susceptible pathogenic bacteria (E. coli, P.aeruginosa and $K$. pneumoniae) were shown in Fig. 8. The lowest MIC was detected at $6.3 \mu \mathrm{g} /$ $\mathrm{ml}$ for $E$. coli and $P$. aeruginosa, respectively, while $K$. pneumonia was less sensitive and its MIC reached to $12.5 \mu \mathrm{g} / \mathrm{ml}$. The results of MICs suggested that AgNPs can be used to control the pathogenic bacterial growth. These results are in accordance with those of (Erjaee et al., 2017) who proved that $7.8 \mu \mathrm{g} / \mathrm{ml}$ was the lowest MIC for $E$. coli. Our results are in contrast with some studies reporting negligible inhibitory effect of silver nanoparticles on E. coli up to $1 \mathrm{mg} / \mathrm{ml}$ (Sondi \& Salopek-Sondi, 2004; PanáčeK et al., 2006). Additionally, (Ping et al., 2005) reported the MIC of silver nanoparticles appeared to be $40 \mu \mathrm{g} / \mathrm{ml}$.

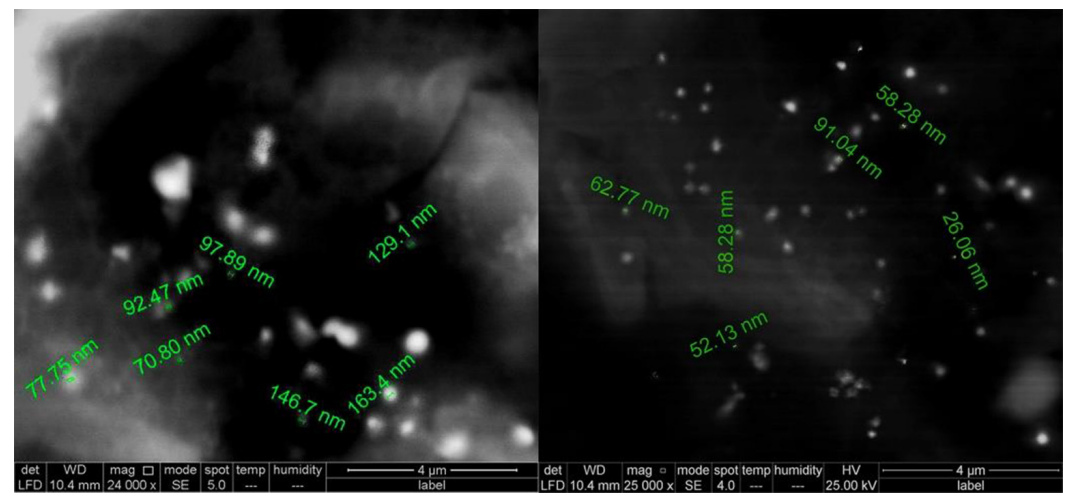

(a)

(b)

Fig. 5. SEM image (micrograph) of the AgNP structures over the ranges of 70-163nm (a) and 26-91nm (b). 


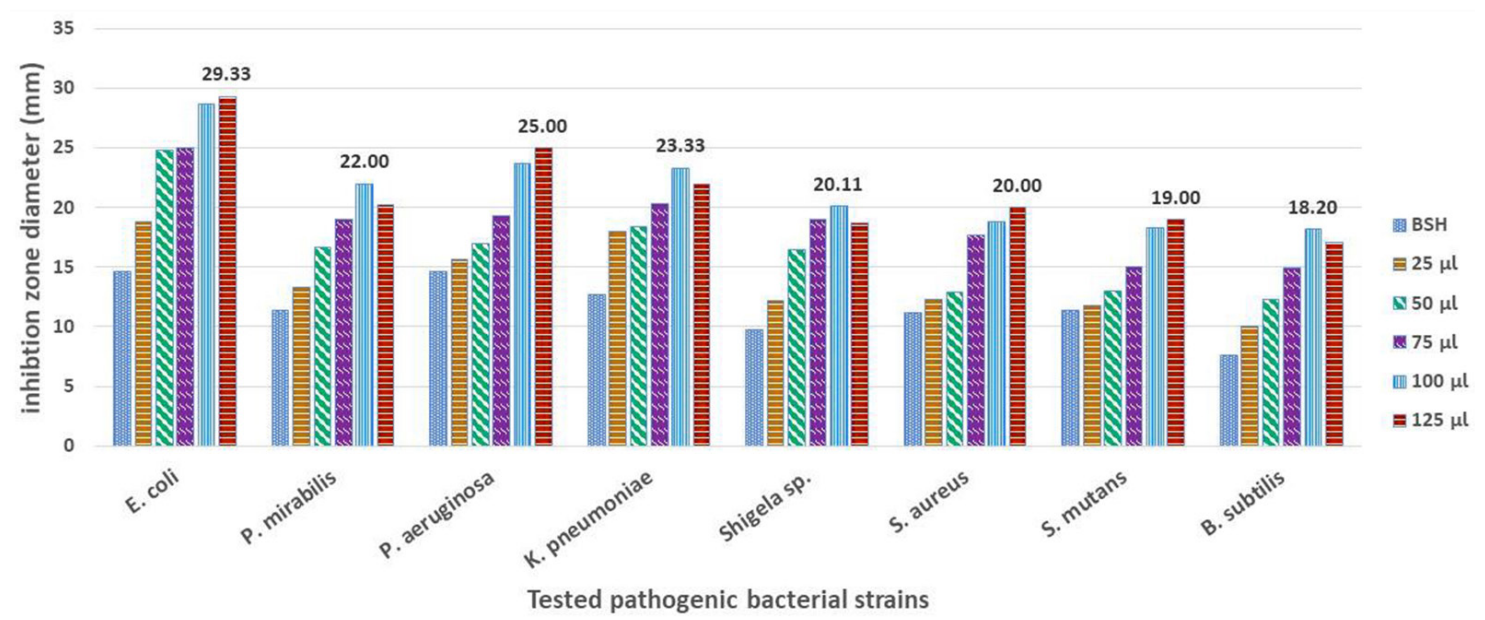

Fig. 6. Antibacterial activity of the synthesized AgNPs against various pathogenic bacterial strains by well diffusion method.

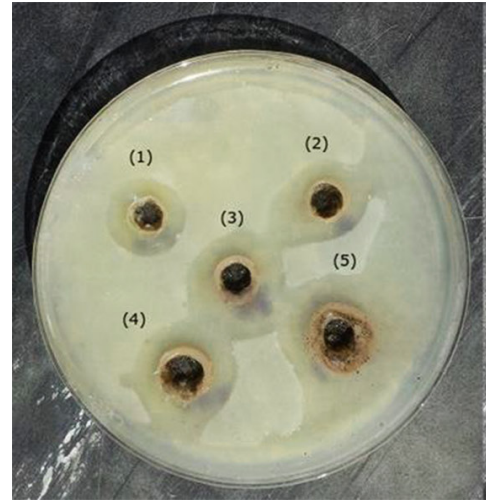

(a)

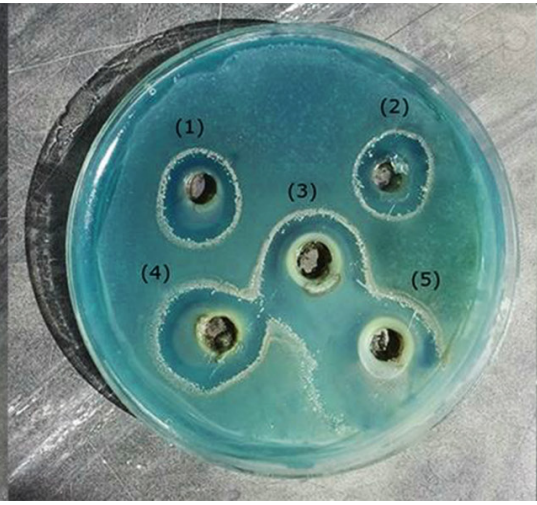

(b)

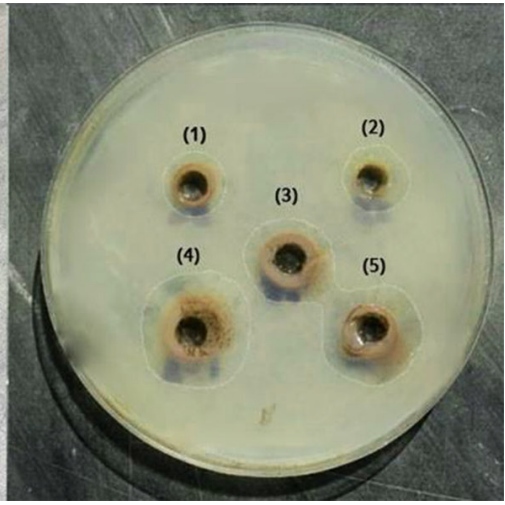

(c)

Fig. 7. Inhibition zones of synthesized AgNPs against (a) E. coli, (b) P. aeruginosa and (c) K. pneumoniae at concentrations of (1) 25, (2) 50, (3) 75 , (4) 100 and (5) $125 \mu \mathrm{l} / \mathrm{ml}$.

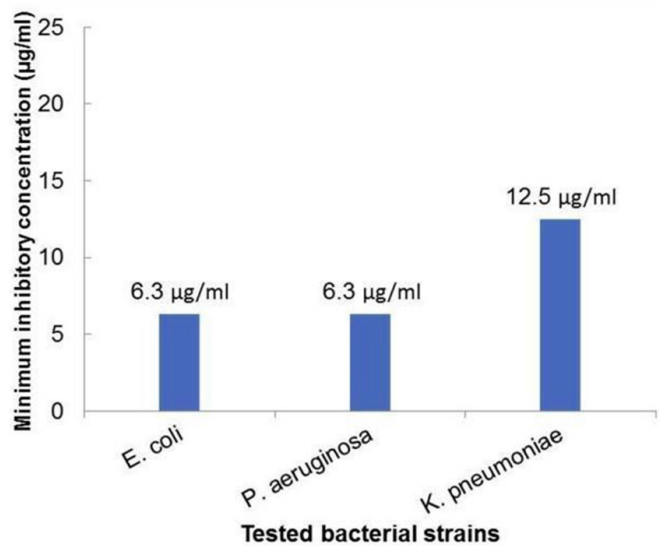

Fig. 8. MICs of the synthesized AgNPs against the most susceptible organisms.
The highest antibacterial activity was investigated by testing AgNPs against bacterial strains and comparing the results for silver salt and natural BSH as illustrated in Fig. 9. The combination of natural BSH with silver nitrate to prepare AgNPs enhances the bactericidal effects. Antibacterial activity against E. coli, Staphylococcus aureus, Streptococcus mutans, Proteus mirabilis, Pseudomonas aeruginosa, and K. pneumonia increased by 2.0-, 1.8-, 1.7-, 1.8-, 1.8- and 1.7-fold, respectively. The highest antibacterial activity of AgNPs was attributed to their extremely large surface area, which provides better contact with microorganisms (Ibrahim, 2015). Moreover, AgNPs have the ability to generate more reactive ionic silver with small 


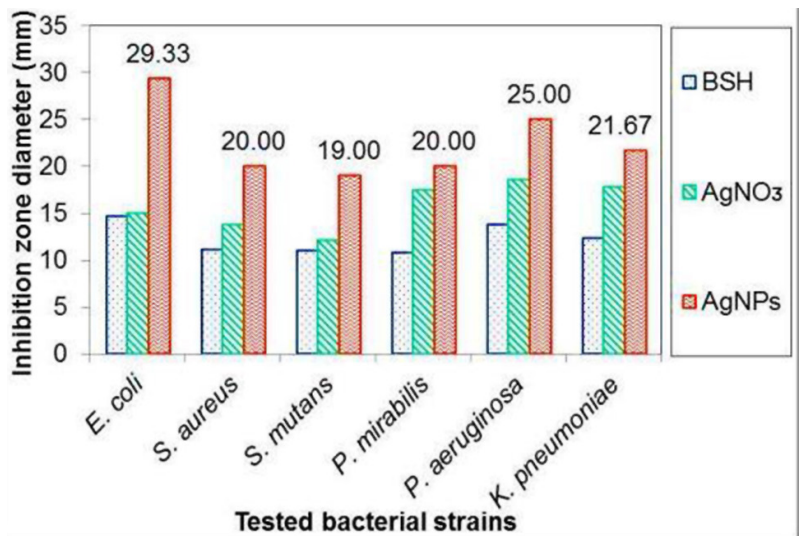

Fig. 9. Comparative antibacterial activity of $\mathrm{BSH}, \mathrm{AgNO}_{3}$ and $\mathrm{AgNPs}$ against the tested pathogenic bacterial strains.

surfaces (Wijnhoven et al., 2009).

\section{Conclusion}

The present study showed a strong, simple and pollutant free eco-friendly approach for synthesizing AgNPs. A local, natural, low cost biological reducing agent, $\mathrm{BSH}$, was applied in an aqueous medium containing $0.1 \mathrm{M} \mathrm{AgNO}_{3}$, employing a green nano-chemistry methodology. The UV-visible spectra confirmed the reduction of the silver ions at $400 \mathrm{~nm}$ after incubation for $72 \mathrm{hr}$ at $9 \mathrm{pH}$ value. The sizes and morphologies of the particles were characterized using SEM and TEM images. The synthesized AgNPs showed more efficient antibacterial activities against the tested Gram-negative than that of Gram-positive bacterial strains. These nanoparticles are effective growth inhibitors against various microorganisms, and thus, they are applicable to diverse medical devices and antimicrobial control systems.

Acknowledgements: The authors are grateful for the support extended by Prof. Dr. Doaa Ahmed Gareeb, Department of Biochemistry, Alexandria University, Alexandria, Egypt, who provided excellent research facilities for some of the biochemical analysis experiments in her lab. This research was partially supported by the National Institute of Oceanography and Fisheries and the High Institute of Public Health.

Disclosure statement: No potential conflicts of interest were reported by the authors.

\section{References}

Ahmed, M.J., Murtaza, G., Mehmood, A., Bhatti, T.M. (2015) Green synthesis of silver nanoparticles using leaves extract of Skimmia laureola: Characterization and antibacterial activity. Materials Letters, 153, 10-13.

Ahmad, N., Sharma, S. (2012) Green synthesis of silver nanoparticles using extracts of Ananas comosus. Green and Sustainable Chemistry, 2, 141.

Albrecht, M. A., Evans, C.W., Raston, C.L. (2006) Green chemistry and the health implications of nanoparticles. Green chemistry, 8, 417-432.

Allahverdiyev, A.M., Kon, K.V., Abamor, E.S., Bagirova, M., Rafailovich, M. (2011) Coping with antibiotic resistance: combining nanoparticles with antibiotics and other antimicrobial agents. Expert Review of Anti-infective Therapy, 9, 1035-1052.

Anastas, P.T., Warner, J.C. (2000) "Green Chemistry: Theory and Practice", Oxford university press Oxford.

Anuj, S.A., Ishnava, K.B. (2013) Plant mediated synthesis of silver nanoparticles by using dried stem powder of Tinospora cordifolia, its antibacterial activity and comparison with antibiotics. International Journal of Pharma and Bio Sciences, 4, 849-863.

Asharani, P.V., Hande, M.P., Valiyaveettil, S. (2009) Anti-proliferative activity of silver nanoparticles. BMC Cell Biol. 10, 65.

Bar, H., Bhui, D.K., Sahoo, G.P., Sarkar, P., Pyne, S., Misra, A. (2009) Green synthesis of silver nanoparticles using seed extract of Jatropha curcas. Colloids and Surfaces A: Physicochemical and Engineering Aspects, 348, 212-216.

Bhainsa, K.C., D'souza, S. (2006) Extracellular biosynthesis of silver nanoparticles using the fungus Aspergillus fumigatus. Colloids and surfaces B: 
Biointerfaces, 47, 160-164.

Blanco, E., Shen, H., Ferrari, M. (2015) Principles of nanoparticle design for overcoming biological barriers to drug delivery. Nat. Biotechnol. 33(9) 941-951.

Cho, K.-H., Park, J.-E., Osaka, T., Park, S.-G. (2005) The study of antimicrobial activity and preservative effects of nanosilver ingredient. Electrochimica Acta, 51, 956-960.

Chua, L.S., Lee, J.Y., Chan, G.F. (2013) Honey protein extraction and determination by mass spectrometry. Analytical and Bioanalytical Chemistry, 405, 3063-3074.

Crooks, R.M., Lemon, B.I., Sun, L., Yeung, L.K., Zhao, M. (2001) Dendrimer-encapsulated metals and semiconductors: synthesis, characterization, and applications. Dendrimers III. Springer.

D Steel, R.G., Torrie, J.H. (1986) "Principles and Procedures of Statistics: A Biometrical Approach", McGraw-Hill.

Dahl, J.A., Maddux, B.L., Hutchison, J.E. (2007) Toward greener nanosynthesis. Chemical Reviews, 107, 2228-2269.

Dibrov, P., Dzioba, J., Gosink, K.K., Häse, C.C. (2002) Chemiosmotic mechanism of antimicrobial activity of $\mathrm{Ag}^{+}$in Vibrio cholerae. Antimicrobial Agents and Chemotherapy, 46, 2668-2670.

Elechiguerra, J.L., Burt, J.L., Morones, J.R., CamachoBragado, A., Gao, X., Lara, H.H., Yacaman, M.J. (2005) Interaction of silver nanoparticles with HIV-1. Journal of Nanobiotechnology, 3, 6.

Erjaee, H., Rajaian, H., Nazifi, S. (2017) Synthesis and characterization of novel silver nanoparticles using Chamaemelum nobile extract for antibacterial application. Advances in Natural Sciences: Nanoscience and Nanotechnology, 8, 025004.

Fayaz, A.M., Balaji, K., Kalaichelvan, P., Venkatesan, R. (2009) Fungal based synthesis of silver nanoparticles - an effect of temperature on the size of particles. Colloids and Surfaces B: Biointerfaces, 74, 123-126.

Fayaz, A.M., Balaji, K., Girilal, M., Yadav, R., Kalaichelvan, P.T., Venketesan, R. (2010) Biogenic synthesis of silver nanoparticles and their synergistic effect with antibiotics: A study against gram-positive and gram-negative bacteria. Nanomedicine: Nanotechnology, Biology and Medicine, 6, 103-109.
French, V., Cooper, R.A., Molan, P.C. (2005) The antibacterial activity of honey against coagulasenegative staphylococci. Journal of Antimicrobial Chemotherapy, 56, 228-231.

Gittins, D.I., Bethell, D., Nichols, R.J., Schiffrin, D.J. (2000) Diode-like electron transfer across nanostructured films containing a redox ligand. Journal of Materials Chemistry, 10, 79-83.

Honary, S., Barabadi, H., Gharaei-Fathabad, E., Naghibi, F. (2013) Green synthesis of silver nanoparticles induced by the fungus Penicillium citrinum. Tropical Journal of Pharmaceutical Research, 12, 7-11.

Hutchison, R., Rodriguez, L. (2008) Capnography and respiratory depression. AJN The American Journal of Nursing, 108, 35-39.

Ibrahim, H.M. (2015) Green synthesis and characterization of silver nanoparticles using banana peel extract and their antimicrobial activity against representative microorganisms. Journal of Radiation Research and Applied Sciences, 8, 265275.

Jyoti, K., Baunthiyal, M., Singh, A. (2016) Characterization of silver nanoparticles synthesized using Urtica dioica Linn. leaves and their synergistic effects with antibiotics. Journal of Radiation Research and Applied Sciences, 9, 217 227.

Kalishwaralal, K., Deepak, V., Pandian, S.R.K., Kottaisamy, M., Barathmanikanth, S., Kartikeyan, B., Gurunathan, S. (2010) Biosynthesis of silver and gold nanoparticles using Brevibacterium casei. Colloids and Surfaces B: Biointerfaces, 77, $257-$ 262.

Kamel, Z., Mahmoud, S., Noha, E. (2016) Biosynthesis, characterization and antimicrobial activity of silver nanoparticles from actinomycetes. Research $J$. of Pharmaceutical Bio and Chem Sciences, 7, 119-127.

Kollef, M.H., Golan, Y., Micek, S.T., Shorr, A.F., Restrepo, M.I. (2011) Appraising contemporary strategies to combat multidrug resistant Gramnegative bacterial infections. Proceedings and Data From the Gram-Negative Resistance Summit. Clinical Infectious Diseases, 53, S33-S55.

Korbekandi, H., Iravani, S., Abbasi, S. (2009) Production of nanoparticles using organisms. Critical Reviews in Biotechnology, 29, 279-306.

Kvitek, L., PanáčEk, A., Soukupova, J., Koláŕ, M., VečEřová, R., Prucek, R., Holecova, M., Zbořil, 
R. (2008) Effect of surfactants and polymers on stability and antibacterial activity of silver nanoparticles (NPs). The Journal of Physical Chemistry C, 112, 5825-5834.

Li, W.-R., Xie, X.-B., Shi, Q.-S., Zeng, H.-Y., YouSheng, O.-Y., Chen, Y.-B. (2010) Antibacterial activity and mechanism of silver nanoparticles on Escherichia coli. Applied Microbiology and Biotechnology, 85, 1115-1122.

Li, X., Xu, H., Chen, Z.-S., Chen, G. (2011) Biosynthesis of nanoparticles by microorganisms and their applications. Journal of Nanomaterials, 2011.

Lusby, P.E., Coombes, A.L., Wilkinson, J.M. (2005) Bactericidal activity of different honeys against pathogenic bacteria. Archives of Medical Research, 36, 464-467.

Marambio-Jones, C., Hoek, E.M. (2010) A review of the antibacterial effects of silver nanomaterials and potential implications for human health and the environment. Journal of Nanoparticle Research, 12, 1531-1551.

Mirzajani, F., Ghassempour, A., Aliahmadi, A., Esmaeili, M.A. (2011) Antibacterial effect of silver nanoparticles on Staphylococcus aureus. Research in Microbiology, 162, 542-549.

Moniruzzaman, M., Yung An, C., Rao, P.V., Hawlader, M.N.I., Azlan, S.A.B.M., Sulaiman, S.A., Gan, S.H. (2014) Identification of phenolic acids and flavonoids in monofloral honey from Bangladesh by high performance liquid chromatography: Determination of antioxidant capacity. BioMed Research International, 2014.

Morones, J.R., Elechiguerra, J.L., Camacho, A., Holt, K., Kouri, J.B., Ramírez, J.T., Yacaman, M.J. (2005) The bactericidal effect of silver nanoparticles. Nanotechnology, 16, 2346.

Nambiar, S., Laessig, K., Toerner, J., Farley, J., Cox, E. (2014) Antibacterial drug development: challenges, recent developments, and future considerations. Clinical Pharmacology \& Therapeutics, 96, 147149.

Nanda, A., Saravanan, M. (2009) Biosynthesis of silver nanoparticles from Staphylococcus aureus and its antimicrobial activity against MRSA and MRSE. Nanomedicine: Nanotechnology, Biology and Medicine, 5, 452-456.

Ndikau, M., Noah, N.M., Andala, D.M., Masika, E. (2017) Green synthesis and characterization of silver nanoparticles using Citrullus lanatus fruit rind extract. International Journal of Analytical Chemistry, 2017.

Nel, A.E., Mädler, L., Velegol, D., Xia, T., Hoek, E.M., Somasundaran, P., Klaessig, F., Castranova, V., Thompson, M. (2009) Understanding biophysicochemical interactions at the nano-bio interface. Nature materials, 8, 543.

Pal, S., Tak, Y.K., Song, J.M. (2007) Does the antibacterial activity of silver nanoparticles depend on the shape of the nanoparticle? A study of the gram-negative bacterium Escherichia coli. Applied and Environmental Microbiology, 73, 1712-1720.

Ouf, S.A., El-Adly, A.A., Mohamed, A-A.H. (2015) Inhibitory effect of silver nanoparticles mediated by atmospheric pressure air cold plasma jet against dermatophyte fungi. Journal of Medical Microbiology, 64(10), 1151-1161.

Ouf, S.A., Mohamed, A-A.H., El-Adly, A.A. (2017) Enhancement of the anti-dermatophytic activity of silver nanoparticles by Q-switched Nd:YAG laser and monoclonal antibody conjugation. Medical Mycology, 55(5), 495-506.

Panáček, A., Kvitek, L., Prucek, R., Koláŕ, M., Večeřová, R., Pizúrová, N., Sharma, V.K., NevěčNá, T.J., Zbořil, R. (2006) Silver colloid nanoparticles: Synthesis, characterization, and their antibacterial activity. The Journal of Physical Chemistry B, 110, 16248-16253.

Parashar, U.K., Saxena, P.S., Srivastava, A. (2009) Bioinspired synthesis of silver nanoparticles. Digest Journal of Nanomaterials \& Biostructures (DJNB), 4(1), 159-166.

Philip, D. (2009) Honey mediated green synthesis of gold nanoparticles. Spectrochimica Acta Part A: Molecular and Biomolecular Spectroscopy, 73, 650653.

Philip, D. (2010) Honey mediated green synthesis of silver nanoparticles. Spectrochim Acta A Mol Biomol. Spectrosc. 75, 1078-81.

Philip, D., Unni, C. (2011) Extracellular biosynthesis of gold and silver nanoparticles using Krishna tulsi (Ocimum sanctum) leaf. Physica E: Lowdimensional Systems and Nanostructures, 43, 13181322 .

Ping, L., Juan, L., Changzhu, W., Qingsheng, W., Jian, L. (2005) Synergistic antibacterial effects of $\beta$-lactam antibiotic combined with silver nanoparticles. Nanotechnology, 16, 1912. 
Ponarulselvam, S., Panneerselvam, C., Murugan, K., Aarthi, N., Kalimuthu, K., Thangamani, S. (2012) Synthesis of silver nanoparticles using leaves of Catharanthus roseus Linn. G. Don and their antiplasmodial activities. Asian Pacific Journal of Tropical Biomedicine, 2, 574-580.

Prabu, H.J., Johnson, I. (2015) Plant-mediated biosynthesis and characterization of silver nanoparticles by leaf extracts of Tragia involucrata, Cymbopogon citronella, Solanum verbascifolium and Tylophora ovata. Karbala International Journal of Modern Science, 1, 237-246.

Priya, A.M., Selvan, R.K., Senthilkumar, B., Satheeshkumar, M., Sanjeeviraja, C. (2011) Synthesis and characterization of CdWO4 nanocrystals. Ceramics International, 37, 2485-2488.

Qi, L., Xu, Z., Jiang, X., Hu, C., Zou, X. (2004) Preparation and antibacterial activity of chitosan nanoparticles. Carbohydrate Research, 339, 26932700 .

Rai, M., Yadav, A., Gade, A. (2009) Silver nanoparticles as a new generation of antimicrobials. Biotechnology Advances, 27, 76-83.

Raveendran, P., Fu, J., Wallen, S.L. (2003) Completely "green" synthesis and stabilization of metal nanoparticles. Journal of the American Chemical Society, 125, 13940-13941.

Rosarin, F.S., Mirunalini, S. (2011) Nobel metallic nanoparticles with novel biomedical properties. $J$ Bioanal Biomed. 3, 085-091.

Sadowski, Z., Maliszewska, I., Grochowalska, B., Polowczyk, I., Kozlecki, T. (2008) Synthesis of silver nanoparticles using microorganisms. Materials Science-Poland, 26, 419-424.

Sarker, S.D., Nahar, L., Kumarasamy, Y. (2007)Microtitre plate-based antibacterial assay incorporating resazurin as an indicator of cell growth, and its application in the in vitro antibacterial screening of phytochemicals. Methods, 42, 321-324.

Schultz, S., Smith, D.R., Mock, J.J., Schultz, D.A. (2000) Single-target molecule detection with nonbleaching multicolor optical immunolabels. Proceedings of the National Academy of Sciences, 97, 996-1001.

Sekhon, B.S. (2010) Metalloantibiotics and antibiotic mimics-an overview. Journal of Pharmaceutical Education and Research, 1, 1.
Sharma, V.K., Yngard, R.A., Lin, Y. (2009) Silver nanoparticles: Green synthesis and their antimicrobial activities. Advances in Colloid and Interface Science, 145, 83-96.

Sheela, N., Muthu, S., Krishnan, S.S. (2010) FTIR, FT Raman and UV-Visible Spectroscopic analysis on Metformin hydrochloride. Asian Journal of Chemistry, 22, 5049.

Shrivastava, S., Bera, T., Roy, A., Singh, G., Ramachandrarao, P., Dash, D. (2007) Characterization of enhanced antibacterial effects of novel silver nanoparticles. Nanotechnology, 18 (2007), 225103

Singh, M., Manikandan, S., Kumaraguru, A. (2011) Nanoparticles: A new technology with wide applications. Research Journal of Nanoscience and Nanotechnology, 1, 1-11.

Sondi, I., Salopek-Sondi, B. (2004) Silver nanoparticles as antimicrobial agent: a case study on E. coli as a model for Gram-negative bacteria. Journal of Colloid and Interface Science, 275, 177-182.

Song, J.Y., Kim, B.S. (2009) Rapid biological synthesis of silver nanoparticles using plant leaf extracts. Bioprocess and Biosystems Engineering, 32, 79.

Su, H.-L., Chou, C.-C., Hung, D.-J., Lin, S.-H., Pao, I.-C., Lin, J.-H., Huang, F.-L., Dong, R.-X., Lin, J.-J. (2009) The disruption of bacterial membrane integrity through ROS generation induced by nanohybrids of silver and clay. Biomaterials, 30, 5979-5987.

Venu, R., Ramulu, T., Anandakumar, S., Rani, V., Kim, C. (2011) Bio-directed synthesis of platinum nanoparticles using aqueous honey solutions and their catalytic applications. Colloids and Surfaces A: Physicochemical and Engineering Aspects, 384, 733-738.

Wijnhoven, S.W., Peijnenburg, W.J., Herberts, C.A., Hagens, W.I., Oomen, A.G., Heugens, E.H., Roszek, B., Bisschops, J., Gosens, I., Van De Meent, D. (2009) Nano-silver-a review of available data and knowledge gaps in human and environmental risk assessment. Nanotoxicology, 3, 109-138.

Williams, D.N., Ehrman, S.H., Pulliam Holoman, T.R. (2006) Evaluation of the microbial growth response to inorganic nanoparticles. J Nanobiotechnology, 4,3 . 


\title{
التصنيع الحيوى للجسيمات النانوية الفضية الصديقة للبيئة من عسل النحل المصري: تقييم أنشطتها المضادة للبكتيريا
}

غادة أمين يوسف، علياء محمود البرعى، مى محفوظ عبد التواب قسم النبات والميكروبيولوجى - كلية العلوم - جامعة الإسكندرية - الإسكندرية - مصر.

\begin{abstract}
يهدف هذا البحث إلى التصنيع الحيوى لجزئيات الفضة النانوية (AgNPs) الصديقة للبيئة من عسل النحل كمنتج

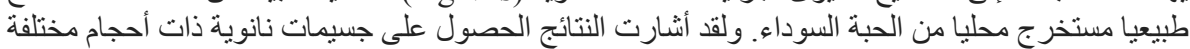

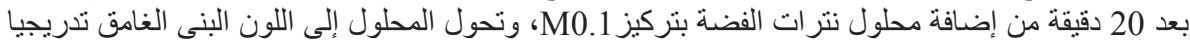

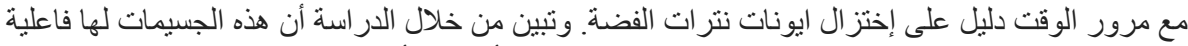

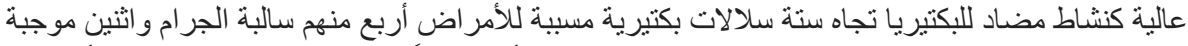

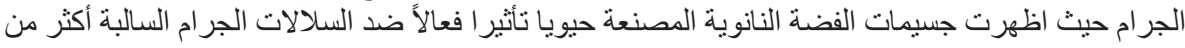

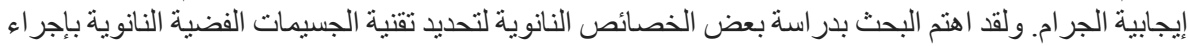

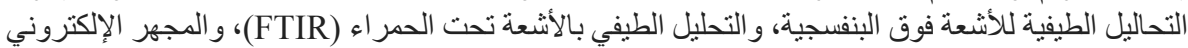

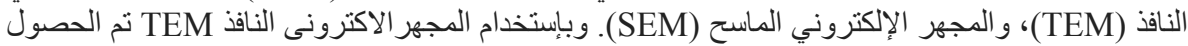

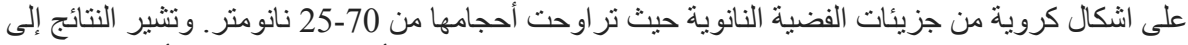

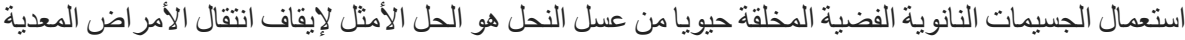
وذلك يعود إلى الصفات الضد ميكروبية لهذه الأجسام بيحث يمكن استخدامها فى العديد من المجلات الطبية الطبية.
\end{abstract}

